\title{
Immunity - a Significant Pathogenic Factor as Well as an Integral Part of the Psychoneuroendocrine-Immune Regulations
}

\section{F. VOŽEH ${ }^{1,2}$}

${ }^{1}$ Department of Pathophysiology, Faculty of Medicine in Pilsen, Charles University, Pilsen, Czech Republic, ${ }^{2}$ Laboratory of Neurodegenerative Disorders, Biomedical Center, Faculty of Medicine in Pilsen, Charles University, Pilsen, Czech Republic

Received April 20, 2017

Accepted November 10, 2017

On-line January 5, 2018

\section{Summary}

Immunity plays an important role in the reactivity of the organism and, in this context, is an essential factor in the pathogenesis of many diseases. Basically, there is no system or organ in the body, whose dysfunction is not related to immunity consequences. In addition, there are also multisystem diseases simultaneously involving multiple body systems. They are not always caused by weak immunity, but also often by modified immune reactions known as overshooting. The essence of all these diseases is a change in the reactivity of the organism where immunity plays an important role. The immunity as such is then part of the systems of neuroendocrine-immune regulation, which have common mediators and receptors. The establishment of psychoneuroimmunology, a relatively new discipline in neuroscience, contributed to a detailed understanding of these mechanisms between central and peripheral nervous system, the endocrine system and the immune system. This research enabled the uncovering of the nature of stress-diseases and impact of other regulatory disturbances on the function of various body organs and systems of the organism as a whole. The aim of this short review is to show complex interconnections of these relationships to better understand the human health and disease.

\section{Key words}

Immunity - Pathogenesis - Psychoneuroimmunology • Psychoneuroendocrine-immune regulations • Stress diseases

\section{Corresponding author}

F. Vožeh, Department of Pathophysiology, Faculty of Medicine in Pilsen, Charles University, Alej Svobody 1655/76, 32300 Plzeň, Czech Republic. E-mail: Frantisek.Vozeh@lfp.cuni.cz

\section{Introduction}

Currently, there is no doubt that immunity plays a significant role in the pathogenesis of many diseases. Essentially, there is no system or organ in the body the impairment of which would not have immunity consequences. Additionally, there are other diseases named multisystem diseases that affect multiple systems in the body at the same time. Yet is it not always a matter of weak immunity, but also modified, often so-called overshooting immune responses that particularly are recently on the rise. Among them are various types of oversensitivities, such as allergies, atopies, anaphylaxes (pollen, food, etc.), where the body responds to allergens from the external environment in this manner.

However, aside from these, there are also autoimmune diseases, where abnormal immune reactions are directed toward the tissues of the body itself. The essence of all (not only) these diseases is a modified response of the body, in which immunity plays a significant role. Nonetheless, it must be emphasized that the mutual influence of both is two-directional. A compromised reactivity can thus be the consequence of immune changes, or affect immunity in its consequences. This points to the influences that are largely internally determined in the body, meaning mostly conditioned by heredity (constitutions, neuroendocrine relations, barrier functions, etc.), as well as by factors of the external environment that can be of various nature and intensity (for example physical, chemical, biological, as well as 
psychological and social).

The result of the effect of these factors upon a given body's reactivity is a various level of bodily prosperity, the determining factors of which are good health on one side or disease and possibly even death on the other. At the same time, all such internal and external factors and influences are mutually, functionally and multilaterally connected in order to best contribute (if possible) to the individual's good health. This is particularly a matter of sustaining stability of the internal environment, homeostasis. It was later completed with a term allostasis which means an additional process of reestablishing homeostasis under variable and changing conditions (Sterling and Eyer 1988). In the optimal case then is important to maintain the harmonious balance of both the homeostasis and allostasis with the influences of the external environment. In opposite situation when allostatic load (mainly in highly civilized society with increased demands in the nervous and mental sphere) is chronically high, then the allostatic overload develops together with various pathological consequences (Vožeh 1994, McEwen 1998, McEwen 2008, McEwen and Wingfield 2003, Mašek et al. 2003) (Fig. 1).

\section{Immunity - a significant part of reactivity of the organism}

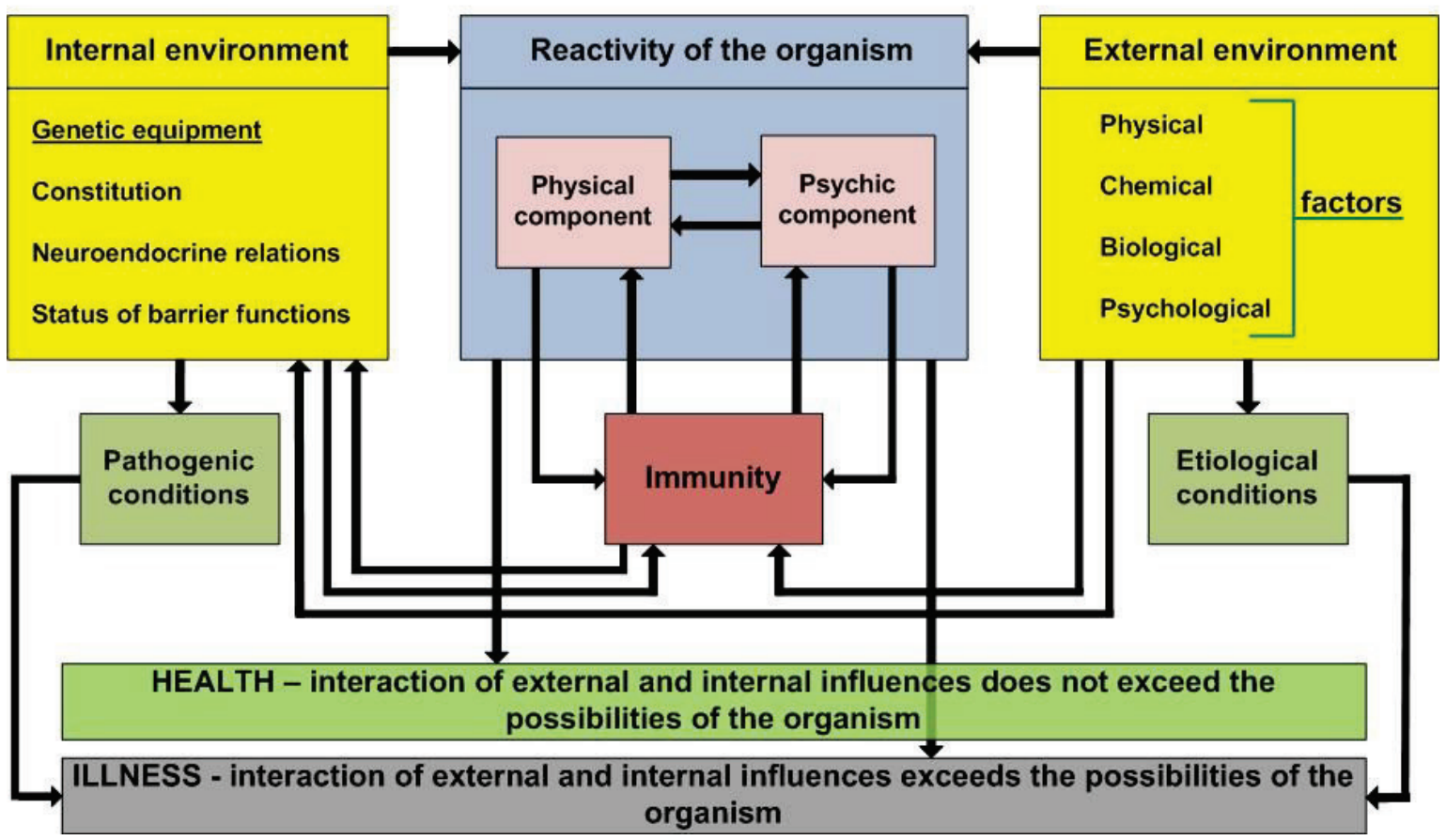

Fig. 1. Immunity - a significant part of reactivity and their interconnectivity with other factors in the context of the whole organism.

\section{Overview of current knowledge of psychoendocrine-immune relations}

Of the number of mechanisms that take place in sustaining normally functional immunity, as well as in cases of immune dysfunctions, it is appropriate to mention psychoneuro-endocrine relations and regulations. It is their knowledge that enables us to understand the changes of body responses, including immunity disorders caused, for example, by psychobiological stress, whether apparent through lower resistance against infections, various allergic reactions or weakened resistance against tumorous growth. Mutual relations between the neuroendocrine and immune systems are mediated through a number of ergones - neurohormones, neurotransmitters, as well as cytokines that are native to both these systems in which they are produced and where they are also actively taking effect (Blalock 1985, Blalock et al. 1985, Besedovsky et al. 1985, Besedovsky and del Rey 1988, Weigent et al. 1990, Ferenčík et al. 1998, Páv et al. 2008, Ganor and Levite 2014, Arreola et al. 2016, Cacabelos 2016) (Table 1). 
Table 1. Joint mediators of the neuroendocrine and immune system.

\begin{tabular}{ll}
\hline Pituitary hormones & Neuropeptides \\
\hline Adrenocorticotropic hormone (ACTH) & (Met) enkephalin \\
Endorphins & Arginine vasopressin (AVP) \\
Thyroid-stimulating hormone (TSH) & Oxytocin \\
Chorionic gonadotrophin (HCG) & Neuropeptide Y \\
Luteinizing hormone (LH) & Vasoactive intestinal peptide (VIP) \\
Follicle-stimulating hormone (FSH) & Somatostatin (SST) \\
Prolactin (PRL) & Insulin-like growth factor 1 (IGF-1) \\
Somatotropic hormone (STH) & \\
\hline Hypothalamic releasing factors & Cytokines formed by some types of glia and neurons \\
\hline Corticotropin-releasing hormone (CRH) & Interleukins IL 1, 6, 10 \\
Somatotropin releasing hormone (SRH) & Interferons IFN $\alpha, \beta, \gamma$ \\
Luteinizing hormone releasing hormone (LH-RH) & Tumor necrosis factor TNF- $\alpha$ \\
& Transforming growth factor TGF $\beta$ \\
& Transforming growth factor TGF $\beta$ \\
& Granulocyte macrophage colony stimulating factor (GM-CSF) \\
& Monocyte chemoattractant protein MCP-1 \\
\hline
\end{tabular}

\section{Gaseous mediators}

Nitric oxide (NO) gas neuro immuno-modulator and general biological messenger acting on the nervous (synaptic transmission, cognition), immune and vascular system

Hydrogen sulphide $\left(\mathrm{H}_{2} \mathrm{~S}\right)$ gas in a neurotransmitter significant induction of hippocampal LTP, nociception, in the periphery is involved in relaxation of smooth-muscle

Carbon monoxide (CO) gas is a general neuromodulator acting both in the peripheral and central nervous system (synaptic plasticity, brain stress control)

All these gases are involved in the regulation of the HPA stress axis in the hypothalamus

The first empirical observations in this area were already conducted in previous centuries by entire generation of doctors beginning with the famous Galen (129-200). Back then he had already stated that melancholic women more often suffer from cancer (Mašek et al. 2003). Also, time-tested and practice-tested truisms and sayings such as "a cheerful mind is one half of health" or "a healthy spirit dwells in a healthy body" should also be understood in this context.

Only in the last three decades of the $20^{\text {th }}$ century was a systematic research initiated in this area, leading in the 1980s to the creation of the interdisciplinary field of psychoneuroimunology (PNI). This originally produced random works, but later works that authors also began conducting systematically in regard to psychoneuroendocrine-immune interactions both in experiments on animals as well as human clinical studies. This is how, for example, behaviorally conditioned immunosuppression was described, as well as its significant role in the programming of neuroendocrine functions in mice (Ader and Cohen 1975, Pierpaoli and Besedovsky 1975). Structurally functional circuits responsible for neuroendocrine-immunity interactions were described, thanks to monitoring the effects of small brain electrolytic lesions on the immunoendocrine function of laboratory rats (Mašek et al. 1992, Petrovický et al. 1994). The impact of inherent cerebellum neurodegeneration on the adrenal glands, thymus and other parts of the lymphatic system of mutants was described, including a contribution from our research team (Beranová et al. 2002, Mand'áková et al. 2005, Vožeh et al. 2014). 
It must be said that certain stages are observable in regard to the overview of the key ergones shared by the immune and neuroendocrine systems (Table 1). They were particularly discovered over the course of the last decades of the $20^{\text {th }}$ century, as well as subsequently until present times. First there were discoveries proving the connection of stress hormones with the HPA axis (hypothalamus - hypophysis - adrenal glands), but later also other peptides, derived from proopiomelanocortin (Blalock et al. 1985, Besedovsky et al. 1985, Smith and Blalock 1988, Besedovsky and del Rey 1988, Carr and Blalock 1988, Bauer 2005).

Shortly thereafter, receptors for these ligands were gradually found, again in both these systems, further confirming a functional two-way communication. The discoveries of this de facto molecular essence of the functional connection of both systems continued alongside exploration in the sense that cytokines native to immunity cells and tissues were identified in the nervous system, produced primarily by glia (Besedovsky and del Rey 1988, Weigent et al. 1990, Ferenčík et al. 1988, Kelley and McCusker 2014, Holzer et al. 2015, Hořejší 2017).

On the other hand, the role of lymphokines and monokines was found, mediating an inflow of information about the current condition of the immunes system into the nervous and endocrine structures, which is absolutely indisputable and crucial for current immunoregulation (Besedovsky and del Rey 1992, Besedovsky and del Rey 2011, Haddad et al. 2002, Leposavić et al. 2011).

Subsequently, all of the above findings concerning neuroendocrine immunity interactions then logically led to the formulation of the concept of the immune system as a sixth sense within the further development of PNI. The essence of this concept lies both in peptides and non-peptides (for example gas neuromediators $\mathrm{NO}, \mathrm{CO}, \mathrm{H}_{2} \mathrm{~S}$ ) shared by both systems (Manusco et al. 2010) as well as cytokines (as ligands of the respective receptors of the immune system) that could form this sixth sense. Along with the classic five senses, this sixth sense is then able to detect various pathogens, tumorous cells or allergens with high sensitivity, as well as the ability to specify and differentiate those native only to the immune system. As a sixth sense, the immune system, together with shared signaling, is then capable of mobilizing the body to respond to specific triggers. All of the above mentioned mechanisms also likely play a role in the famous "placebo effect" (Blalock and Smith 2007).
The next stage of approach to a developing PNI particularly regards the role of psychology, stress and behavior factors which, as mentioned above, were already considered significant in the disease pathogenesis much earlier in history. However, a systematic research of these mechanisms and particularly scientific proofs concerning this are mostly a matter of the $21^{\text {st }}$ century.

Although considered a threat these days, stress (or more precisely a stress response) is in essence a very useful ability in the adaptation of complex organisms, including humans and it can be stated with certainty that if this was not the case, many animals would have no chance of surviving. On the other hand, if the stress is intense and long-term and, additionally, if this stress is of so-called psychobiological or psychosocial nature in the case of modern humans, which creates greater psychological than physical demands, than this "good servant turns into a bad master". This then becomes a significant pathogenetic factor in the case of psychosomatic diseases, which could also be called stress diseases and disorders.

Unfortunately, these represent an everexpanding number these days (Kemeny and Schedlowski 2007). The study of pathogenetic mechanisms of these diseases in relation to disturbed psychoneuroendocrineimmune regulations is particularly a matter of the last two decades and still continues. For example, the theory of Professor Charvát and his colleagues (Charvat et al. 1964) and revolutionary in its day, was developed in detail, proving a causal relation between chronic mental stress and myocardial infarction. However, only recent studies have shown the participation of anti-inflammatory cytokines and this in relation to both acute and chronic ischemic heart disease. The essential role of stress-related sleep disorders in relation to the release of these cytokines was also found in this relation. This proved the importance of quality sleep as a cardinal factor in development of both acute (myocardial infarction, acute cerebral stroke) and chronic circulatory diseases (Skinner et al. 2009, Motivala 2011).

Another significant area, where the research of psychoneuroendocrine-immune relations brought fundamental new findings, was the area of tumorous diseases. In this area, it has been a long-known fact that weakened immunity (for example due to long-term stress or other reasons, such as AIDS) is accompanied by a higher occurrence of tumors. However, only the research of the last few years specifically explained the participation of etiopathogenetic mechanisms within 
the psychoneuroendocrine-immune mechanisms in tumorigenesis, including a ratio of the individual anti-tumorous cytokines, the involvement of epiphysis, as well as two-way signaling between the tumor and the brain with subsequent modulation of neuroendocrineimmunity functions (Reiche et al. 2004, Ondicova and Mravec 2010, Lissoni 2012, Skřrivanová et al. 2014).

The continuing research also identified notable findings and consequences between compromised psychoneuroendocrine-immune relations in diseases belonging to the fields of psychiatry, skin and eye medicine.

In psychiatric diseases this specifically involves the relationship between depression and decreased immunity. Particularly depressions are evidently coresponsible, for example, for both the formation of tumors and the course of these diseases with a direct impact on the survival expectancy period. The same thing is true in case of infectious diseases, where it is also a consequence of a depression-induced immunosuppression, as well as impairment of many multidirectional neuroendocrine-immunity interactions (Besedovsky et al. 1996, Irwin and Miller 2007, Smith 2015).

Surprising, although not greatly surprising, were also the recent discoveries in the pathogenesis of schizophrenia. Here, clear evidence proved a causal connection between anti-inflammatory cytokines found in increased amounts in the cerebrospinal fluid of the patients. Both the results of experiments on animal models and the epidemiological studies of humans proved a significant role of the early impairment of immunity for later increased immune reactivity. These studies showed that severe infections and autoimmune diseases could be risk factors for schizophrenia. Also, genetic research confirmed similar results in regard to this disease being "inflammatory", identifying a connection between schizophrenia and chromosome 6 p22.1 in an area that relates to the human leukocyte antigen system of human tissue antigens and other immune functions. This "inflammation" theory is also indirectly supported by the significant therapeutic effect of anti-inflammatory medications and antipsychotic medications with similar effect (Schubert 2014, Müller et al. 2015).

In relation to skin diseases, here the new discoveries reach all the way to the molecular level, confirming the well-known rule of ancient medical practitioners that "skin is the mirror of the body", with the addition that the psychoneuroendocrine-immune subtext of the disease relates to psychosomatics. This was specifically proven in such skin diseases as atopic dermatitis, psoriasis, as well as malignant melanoma, the most frequent and continually increasing current diseases (Moynihan et al. 2010, Peters 2016).

And finally, although it is surprising, eye impairments also show etiopathogenetic consequences and have a continually and increasingly evident relation to psychoneuroendocrine-immune dysregulations. As shown by research focused in this direction, this subtext applies in the case of glaucoma, dry keratitis, atopic keratoconjunctivitis, uveitis, and the ever more frequent macular degeneration and eye malignancies (Ventura 2009). Also findings that re-evaluate and supplement the knowledge of the functional morphological substrate of these relations with the surprisingly significant role of enteric nervous system (ENS), known also as "gut brain" and colon microbiota, are among the latest significant discoveries in the PNI area, with an impact on many physical systems, as well as organs and actually on the organism as a whole. It is now without doubt that there is a two-way functional gut-brain axis to which both ENS and the rich colon immune system and microbiota contribute. Here should be also emphasized that the beginning of intestine colonization by useful bacteria in newborns starts with normal physiological mode of birth and further then by prebiotics in maternal milk that positively affect function of the gut-brain axis (Rautava et al. 2012, Makino et al. 2013, Oliveros et al. 2015, Vazquez et al. 2016, Mittal et al. 2017).

Based particularly on experimental research on "germ-free" rodents, colon microbiota is specifically attributed with the key role in the development of emotional behavior, stress and pain-modulating systems, as well as function of brain neurotransmitter systems. The above seemingly revolutionary findings are not as surprising if we consider the amount of bacteria in the colon (equal to the number of cells in the human body), the massive immune system (representing the largest amassing of this tissue in the body), as well as the amount of neurons (equal to their amount in the spinal cord over 100 million). In any case these findings bring further understanding of diseases such as irritable bowel syndrome, autism, anxieties, depression, as well as neurodegeneration (for example Parkinson's disease) (Collins et al. 2012, Bailey 2014, Borre et al. 2014, Lyte 2014, Mayer et al. 2015).

Aside from the above list of negative impact of 
psychoneuroendocrine-immune dysregulations, some of their positive influences should also be mentioned, as they are capable of preventively avoiding these impairments or subsequently mitigating them. This means that life should be harmonized in such way that stress situations are balanced with activities and experiences that positively influence both the body and the psyche. This is both quantitatively and qualitatively different for each individual, but the result should be a positive thinking and balanced optimistic world view (Steptoe et al. 2009, Boehm and Kubzansky 2012).

Despite the personality differences mentioned, here we can also find a common denominator, such as music - and not just any music. Regardless of the relatively individual approach to different styles of music, as a relaxation phenomena (increasing stress resistance, showing an evident positive impact on immunity), publications do differ and this holds true regarding specific composers. Mozart's music is absolutely clearly preferred in this regard, given that the relaxation effect and particularly the positive impact on selected immunity parameters (certain cytokines and interferon-gamma) was evidently more apparent than in the Beethoven and Schubert compositions (Kimata 2003, Okada et al. 2009, Fancourt et al. 2014).

\section{Conclusions}

To conclude this paper, it must be stated that the etiopathogenesis of diseases is a far more complex matter than even the most significant representatives of modern medicine (even as late as the $20^{\text {th }}$ century) could ever imagine. As mentioned in the introduction, the occurrence of diseases is conditioned by the body's reaction under the influence of immunity and vice versa. All this is a close relation to the personality type that is conditioned genetically, as well as formed by other influences of the external and internal environment over the course of lifetime and in each given moment. This confirms all postulates regarding the unity of body and soul known from ancient history, but the scientific evidence concerning this was brought about by modern sciences, particularly through the formation of the PNI. This field finally proved the interconnectedness of the psychoneuroendocrine-immune relations and regulation in the sustainance of homeostasis of the organism, as well as the pathogenesis of practically all diseases related to its disruption.

This laid the foundations both for a correct understanding of an organism as a dynamic unit in health and illness and opened new possibilities of a complex approach to the prevention and treatment of diseases. On one hand, this means that we must continually see the patient's body as a whole and treat it in this manner. On the other hand, we must influence the respective known pathogenetic mechanisms of diseases on cellular, subcellular or even molecular levels in a sensitive and targeted manner.

At the same time, this points to the need to create an individualized medicine, tailor-made to the personality of the patient.

\section{Conflict of Interest}

There is no conflict of interest.

\section{Acknowledgements}

This study was supported by the Charles University Research Fund (project number Q39) and by the National Sustainability Program I (NPU I) Nr. LO1503 provided by the Ministry of Education, Youth and Sports of the Czech Republic. The author would like to thank to Mrs. Michaela Freeman for language editing the manuscript and to Ing. Zuzana Petránková, Ph.D. for drawing up the picture.

\section{References}

ADER R, COHEN N: Behavioraly conditioned immunosuppression. Psychosom Med 37: 333-340, 1975.

ARREOLA R, ALVAREZ-HERRERA S, PÉREZ-SÁNCHEZ G, BECERRIL-VILLANUEVA E, CRUZ-FUENTES C, FLORES-GUTIERREZ EO, GARCÉS-ALVAREZ ME, DE LA CRUZ-AGUILERA DL, MEDINA-RIVERO E, HURTADO-ALVARADO G, QUINTERO-FABIÁN S, PAVÓN L: Immunomodulatory effects mediated by dopamine. J Immunol Res 2016: 3160486, 2016.

BAILEY MT: Influence of stressor-induced nervous system activation on the intestinal microbiota and the importance for immunomodulation. Adv Exp Med Biol 817: 255-276, 2014.

BAUER ME: Stress, glucocorticoids and ageing of the immune system. Stress 8: 69-83, 2005. 
BERANOVÁ M, MANĎÁKOVÁ P, ŠÍMA P, SLÍPKA J, VOŽEH F, KOČOVÁ J, ČERVINKOVÁ M, SÝKORA J: Morphology of adrenal gland and lymph organs is impaired in neurodeficient Lurcher mutant mice. Acta Vet 71: 23-28, 2002.

BESEDOVSKY HO, DEL REY A: Interactions between immunological cells and the hypothalamus pituitary-adrenal axis: an example of neuroendocrine immunoregulation. Recenti Prog Med 79: 300-304, 1988.

BESEDOVSKY HO, DEL REY A: Immune-neuroendocrine circuits: integrative role of cytokines. Front Neuroendocrinol 13: 61-94, 1992.

BESEDOVSKY HO, DEL REY A: Central and peripheral cytokines mediate immune-brain connectivity. Neurochem Res 36: 1-6, 2011.

BESEDOVSKY HO, DEL REY A, SORKIN E: Immune-neuroendocrine interactions. J Immunol 135 (2 Suppl): $750 \mathrm{~s}-754 \mathrm{~s}, 1985$.

BESEDOVSKY HO, HERBERMAN RB, TEMOSHOK LR, SENDO F: Psychoneuroimmunology and cancer: Fifteenth Sapporo Cancer Seminar. Cancer Res 56: 4278-4281, 1996.

BLALOCK JE: Proopiomelanocortin-derived peptides in the immune system. Clin Endocrinol (Oxf) 22: 823-827, 1985.

BLALOCK JE, SMITH EM: Conceptual development of the immune system as a sixth sense. Brain Behav Immun 21: 3-33, 2007.

BLALOCK JE, SMITH EM, MEYER WJ: The pituitary-adrenocortical axis and the immune system. Clin Endocrinol Metab 14: 1021-1038, 1985.

BOEHM JK, KUBZANSKY LD: The heart's content: the association between positive psychological well-being and cardiovascular health. Psychol Bull 138: 655-691, 2012.

BORRE YE, MOLONEY RD, CLARKE G, DINAN TG, CRYAN JF: The impact of microbiota on brain and behavior: mechanisms \& therapeutic potential. Adv Exp Med Biol 817: 373-403, 2014.

CACABELOS R, TORRELLAS C, FERNÁNDEZ-NOVOA L, LÓPEZ-MUÑOZ F: Histamine and immune biomarkers in CNS disorders. Mediators Inflamm 2016: 1924603, 2016.

CARR DJ, BLALOCK JE: "Classical" neuroendocrine peptide hormones produced by cells of the immune system. Brain Behav Immun 2: 328-334, 1988.

CHARVAT J, DELL P, FOLKOW B: Mental factors and cardiovascular diseases. Cardiologia 44: 124-141, 1964.

COLLINS SM, SURETTE M, BERCIK P: The interplay between the intestinal microbiota and the brain. Nat Rev Microbiol 10: 735-742, 2012.

FANCOURT D, OCKELFORD A, BELAI A: The psychoneuroimmunological effects of music: a systematic review and a new model. Brain Behavior Immunity 36: 15-26, 2014.

FERENČÍK M, NOVÁK M, ROVENSKÝ J: Relation and interactions between the immune and neuroendocrine systems (in Slovak). Bratisl Lek Listy 99: 454-464, 1998.

GANOR Y, LEVITE M: The neurotransmitter glutamate and human T cells: glutamate receptors and glutamate-induced direct and potent effects on normal human $\mathrm{T}$ cells, cancerous human leukemia and lymphoma $\mathrm{T}$ cells, and autoimmune human T cells. J Neural Transm (Vienna) 121: 983-1006, 2014.

HADDAD JJ, SAADÉ NE, SAFIEH-GARABEDIAN B: Cytokines and neuro-immune-endocrine interactions: a role for the hypothalamic-pituitary-adrenal revolving axis. J Neuroimmunol 133: 1-19, 2002.

HOLZER P, HASSAN AM, JAIN P, REICHMANN F, FARZI A: Neuroimmune pharmacological approaches. Curr Opin Pharmacol 25: 13-22, 2015.

HOŘEJŠÍ V: Dialogue of immunity with the nervous and endocrine system (in Czech). Vesmir 96: 552-553, 2017.

IRWIN MR, MILLER AH: Depressive disorders and immunity: 20 years of progress and discovery. Brain Behav Immun 21: 374-383, 2007.

KELLEY KW, MCCUSKER RH: Getting nervous about immunity. Semin Immun 26: 389-393, 2014.

KEMENY ME, SCHEDLOWSKI M: Understanding the interaction between psychosocial stress and immune-related diseases: a stepwise progression. Brain Behav Immun 21: 1009-1018, 2007.

KIMATA H: Listening to Mozart reduces allergic skin wheal responses and in vitro allergen-specific IgE production in atopic dermatitis patients with latex allergy. Behav Med 29: 15-19, 2003.

LEPOSAVIĆ G, PILIPOVIĆ I, PERISIĆ M: Cellular and nerve fibre catecholaminergic thymic network: steroid hormone dependent activity. Physiol Res 60 (Suppl 1): S71-S82, 2011. 
LISSONI P: A reinterpretation of the pathogenesis and cure of cancer according to the psychoneuroimmunological discoveries. Methods Mol Biol 934: 183-192, 2012.

LYTE M: The effect of stress on microbial growth. Anim Health Res Rev 15: 172-174, 2014.

MAKINO H, KUSHIRO A, ISHIKAWA E, KUBOTA H, GAWAD A, SAKAI T, OISHI K, MARTIN R, BEN-AMOR K, KNOL J, TANAKA R: Mother-to-infant transmission of intestinal bifidobacterial strains has an impact on the early development of vaginally delivered infant's microbiota. PLoS One 8: 1-10, 2013.

MANCUSO C, NAVARRA P, PREZIOSI P: Roles of nitric oxide, carbon monoxide, and hydrogen sulfide in the regulation of the hypothalamic-pituitary-adrenal axis. J Neurochem 113: 563-575, 2010.

MANĎÁKOVÁ P, ŠINKORA J, ŠÍMA P, VOŽEH F: Reduced primary T lymphopoiesis in 3-month-old lurcher mice: sign of premature ageing of thymus? Neuroimmunomodulation 12: 348-356, 2005.

MAŠEK K, PETROVICKÝ P, SEIFERT J: An introduction to the possible role of central nervous system structures in neuroendocrine-immune interactions. Int J Immunopharmacol 14: 317-322, 1992.

MAŠEK K, SLÁNSKÝ J, PETROVICKÝ P, HADDEN JW: Neuroendocrine immune interactions in health and disease. Int Immunopharmacol 3: 1235-1246, 2003.

MAYER EA, TILLISCH K, GUPTA A: Gut brain axis and the microbiota. $J$ Clin Invest 125: 926-938, 2015.

MCEWEN BS: Stress, adaptation, and disease: allostasis and allostatic load. Ann NY Acad Sci 840: 33-44, 1998.

MCEWEN BS: Central effects of stress hormones in health and disease: Understanding the protective and damaging effects of stress and stress mediators. Eur J Pharmacol 583: 174-185, 2008.

MCEWEN BS, WINGFIELD JC: The concept of allostasis in biology and biomedicine. Horm Behav 43: 2-15, 2003.

MITTAL R, DEBS LH, PATEL AP, NGUYEN D, PATEL K, O'CONNOR G, GRATI M, MITTAL J, YAN D, ESHRAGHI AA, DEO SK, DAUNERT S, LIU XZ: Neurotransmitters: the critical modulators regulating gut-brain axis. $J$ Cell Physiol 232: 2359-2372, 2017.

MOTIVALA SJ: Sleep and inflammation: psychoneuroimmunology in the context of cardiovascular disease. Ann Behav Med 42: 141-152, 2011.

MOYNIHAN J, RIEDER E, TAUSK F: Psychoneuroimmunology: the example of psoriasis. Ital Dermatol Venereol 145: 221-228, 2010.

MÜLLER N, WEIDINGER E, LEITNER B, SCHWARZ MJ: The role of inflammation in schizophrenia. Front Neurosci 9: 372, 2015.

OKADA K, KURITA A, TAKASE B, OTSUKA T, KODANI E, KUSAMA Y, ATARASHI H, MIZUNO K: Effects of music therapy on autonomic nervous system activity, incidence of heart failure events, and plasma cytokine and catecholamine levels in elderly patients with cerebrovascular disease and dementia. Int Heart $J$ 50: 95-110, 2009.

OLIVEROS E, RAMIREZ M, VAZQUEZ E, BARRANCO A, GRUART A, DELGADO-GARCIA JM, BUCK R, RUEDA R, MARTIN MJ: Oral supplementation of 2'-fucosyllactose during lactation improves memory and learning in rats. J Nutr Biochem 31: 20-27, 2016.

ONDICOVA K, MRAVEC B: Role of nervous system in cancer aetiopathogenesis. Lancet Oncol 11: 596-601, 2010.

PÁV M, KOVÁŘŮ H, FIŠEROVÁ A, HAVRDOVÁ E, LISÁ V: Neurobiological aspects of depressive disorder and antidepressant treatment: role of glia. Physiol Res 57: 151-164, 2008.

PETERS EM: Stressed skin? - a molecular psychosomatic update on stress-causes and effects in dermatologic diseases. J Dtsch Dermatol Ges 14: 233-252, 2016.

PETROVICKÝ P, MAŠEK K, SEIFERT J: Brain regulatory system for the immune response: immunopharmacology and morphology. Neuroimmunomodulation 1: 165-173, 1994.

PIERPAOLI W, BESEDOVSKY HO: Role of the thymus in programming of neuroendocrine functions. Clin Exp Immunol 20: 323-338, 1975.

RAUTAVA S, LUOTO R, SALMINEN S, ISOLAURI E: Microbial contact during pregnancy, intestinal colonization and human disease. Nat Rev Gastroenterol Hepatol 12: 565-576, 2012.

REICHE EM, NUNES SO, MORIMOTO HK: Stress, depression, the immune system, and cancer. Lancet Oncol 5: 617-625, 2004.

SCHUBERT C: Psychoneuroimmunology of the life span: impact of childhood stress on immune dysregulation and inflammatory disease in later life. Psychother Psychosom Med Psychol 64: 171-180, 2014. 
SKINNER R, GEORGIOU R, THORNTON P, ROTHWELL N: Psychoneuroimmunology of stroke. Immunol Allergy Clin North Am 29: 359-379, 2009.

SKŘIVANOVÁ K, GREGOR J, BENDOVÁ M, BRANČÍKOVÁ D, ELFMARKOVÁ N, SVĚRÁK T, PETERKOVÁ H, DUŠEK L: Psychoneuroimmunology in context of comprehensive breast cancer treatment (in Czech). Klin Onkol 27: 103-107, 2014.

SMITH EM, BLALOCK JE: A molecular basis for interactions between the immune and neuroendocrine systems. Int $J$ Neurosci 38: 455-464, 1988.

SMITH HR: Depression in cancer patients: Pathogenesis, implications and treatment. Oncol Lett 9: 1509-1514, 2015.

STEPTOE A, DOCKRAY S, WARDLE J: Positive affect and psychobiological processes relevant to health. J Pers 77: 1747-1776, 2009.

STERLING P, EYER J: Allostasis: a new paradigm to explain arousal pathology. In: Handbook of Life Stress, Cognition and Health. FISHER S, REASON JT (eds), John Wiley \& Sons, New York, 1988, pp 629-649.

VAZQUEZ E, BARRANCO A, RAMIREZ M, GRUART A, DELGADO-GARCIA JM, JIMENEZ ML, BUCK R, RUEDA R: Dietary 2'-fucosyllactose enhances operant conditioning and long-term potentiation via gut-brain communication through the vagus nerve in rodents. PLoS One 11: e0166070, 2016.

VENTURA LM: Erratum: Psychoneuroimmunology: application to ocular diseases. J Ocul Biol Dis Infor 2: 109-118, 2009.

VOŽEH F: Immunity and pathogenesis (in Czech). Plzen Lek Sb (Suppl 69): 247-249, 1994.

VOŽEH F, SLÍPKA J, KRÁLÍČKOVÁ M: Lurcher mice - a model not only cerebellar degeneration but also neuroendocrino-immune consequences. Comparative morphology (in Czech). Abstracts, Symposium held in honor of prof. MD. RNDr. Jaroslav Slipka, DSc., held in Pilsen on January 14, 2014 by Department of Histology and Embryology and Department of Anatomy, Faculty of Medicine in Pilsen, Charles University and by Czech Anatomical Society, 39-42, 2014.

WEIGENT DA, CARR DJ, BLALOCK JE: Bidirectional communication between the neuroendocrine and immune systems. Common hormones and hormone receptors. Ann NY Acad Sci 579: 17-27, 1990. 